\title{
Reflections on Pottery Art in the Oil Rich Niger Delta Region of Nigeria: A Study of Pottery Art in Akwa Ibom and Rivers States
}

\author{
Edem Etim Peters
}

\begin{abstract}
Niger Delta region is very rich in oil and gas deposits, clay, agricultural land, fisheries, extensive forest and other resources. They are nine states which make the region namely, Abia, Akwa Ibom, Bayelsa, Cross River, Delta, Edo, Imo, Ondo and Rivers. The most oil producing communities among them are Akwa Ibom, Bayelsa, Edo, Delta and Rivers State. Clay is equally found in abundance in all the states like crude oil is found in Niger Delta communities. The available clay mineral in the region has the capacity to transform the nation's economy if properly utilized. Clay is the basic material for pottery or ceramics production. It is also used to ease the penetration of pipes in drilling of crude oil. This paper looks at the practice of pottery in Niger Delta Area with a focus on pottery practice in both Akwa Ibom and Rivers States. Indigenous and contemporary pottery or ceramics practices in these communities indeed have played vital role in the economic, social religious and cultural ways of life of the people. Clay products such as dinnerware and sanitary wares and others are highly sought for and they have the capacity to boast the national economy as experienced in other nations such as Japan, Italy, Britain, United States of America, India and China among others. Data were collected from both primary and secondary sources and were subsequently assessed. The result shows that proper utilization of clay found in Niger Delta has the potential to create numerous job opportunities for the teaming population of youths in the region. The availability of abundant clay in the region, if well harnessed could adequately compete with crude oil exploitation for economic purposes in the region.
\end{abstract}

Index Terms-Ceramics Production; Contemporary; Clay; Crude Oil; Indigenous; Pottery; Transform.

\section{INTRODUCTION}

Niger Delta Region in Nigeria plays the role a major national income generator to cater for every other region since the country depends basically on crude oil sourced from the area. It is therefore the life-wire of Nigeria economy. According to the Central Bank of Nigeria "The region is blessed with mineral resources and accounted for about $90 \%$ of the country's total revenue [2].

Eventhough the region comprises of nine states namely: Abia, Akwa Ibom, Bayelsa, Cross River, Delta, Edo, Imo, Ondo and Rivers, but the most oil producing communities in the Niger Delta Region are Akwa Ibom, Bayelsa, Edo, Delta and Rivers States. It has been realized that clay mineral is deposited in abundant quantity in all the states of Niger Delta Area.

Published on March 24, 2019

E. E. Peters is with the Department of Fine Arts and Design (Ceramics Unit), University of Port Harcourt, Port Harcourt, Nigeria. (email: edem.peters@yahoo.com,edem.peters@uniport.edu.ng)
"Niger Delta is blessed with abundance of physical and human resources, including the majority of Nigeria"s oil and gas deposits, good agricultural land, extensive forest, excellent fisheries, as well as good industrial developmental base in a vibrant primary sector, yet the region remain undeveloped" [3]. It is envisaged that the abundant clay mineral deposited in Niger Delta Communities if adequately utilized can boost a vibrant industrial developmental base as applicable in China, Japan, India, Italy, United Kingdom, United States of America and other nations of the world. The discovery of oil in Niger Delta in the 1950s has yielded so much income for Nigeria as a nation although no significant impact of the income generated is felt in the region in terms of economic growth of the area.

The exploration of clay mineral which will spring up various industries for production of electrical insulators, dinnerware wares, floor tiles, bricks, sanitary wares, engine plugs and other pottery or ceramic products. It is likely easier to create various industries using clay than the crude oil to generate numerous job opportunities and wealth generally.

The use of clay by different cultures for indigenous utilitarian wares in Niger Delta communities has an agelong history [19]. "The people of Ibibioland, South-South Nigeria have been known to have practiced pottery production for a very long time. The practice has been on before the arrival of the Europeans to the area before 1887 AD”. Apart from the Ibibios, other cultures in Niger Delta area such as Orohbo, Isoko, Efiks, Ejagam, Andoni, Ogoni, Ikwere, Edo, Kilabari, Ijaw, Ishekiri, Ison, Ekoi, Opobo and others engage in the traditional pottery production from time immemorial to cater for making of domestic wares to suit their different traditions.

Various clay wares such as water pot, bowls, plates, sieve, ritual crucibles, fortunes tellers pot, cooking pot, ceremonial pot, pots for presentation of grains, musical pot, stationary palm wine pot, pot for saving of money and many others were produced by different tribes and communities in Niger Delta to suit their cultures, religions and socioeconomic endeavours. "Religions and cultures are interwoven and therefore man on the practice of magic and religions had from the beginning learned to fashion or model human and animal figures in clay" [19]. This was applicable to the various cultural entities in Niger Delta area. The use of clay engendered the indigenous creative prowess of the people as well as local industries religion and commerce.

"The sacred of ritual pot was used for definition and was highly decorated" [7]. It was an expression of the peoples' creativity and skills. "Since the white men had not imported 
their influence as yet, then the crafts, arts and designs of the Ibibio could convincingly be seen as original and down to earth in local concepts and functions to be termed indigenous. The works were termed indigenous in the sense that the cultural, beliefs, practice, customs, arts, laws, morals and any other capability of habits acquired by man as a member of the society, no matter how complex were continuously transmitted from generation to generation" [19] What were peculiar to indigenous pottery practices of the Ibibios in Akwa Ibom State seemed to have been likely applicable to the traditional pottery practice of other cultures in the Niger Delta Area. The bountiful natural endowments in Niger Delta region uniquely make the region it stands out in the global highlights of special territories. That [10] gave the following analysis to show the population spare potentials and growth of the region;

The area from the bifurcation of the Niger River at Aboh, founded in West by Benin River and East by Imo River; total area put at 25,000 sq.km by environmental Resources Manager Limited (ERML 1997) report, 20,000 sq.km by 1995 (World Bank report), between 40,000 and 70,000 by Niger Delta Environmental Survey (NDES) ad 112,000 sq.km (NNDC Regional Plan). Since that time, the region has a steadily growing population estimated to be over 30 million. People of 2005, accounting for more than one quarter of Nigeria total population. The population is expounding at a rapid rate of $3 \%$ per year and oil capital, Port Harcourt, along with other, large towns are growing quickly (Wikipedia n.d).

The paper is reflecting on the pottery art in the oil rich Niger Delta Region of Nigeria with a focus on pottery practice in Akwa Ibom State and Rivers State which are among the major oil producing communities. These communities not only experience the indigenous pottery activities but also later involved in the contemporary pottery or ceramics practice so many decades ago. "Murray [15] could be reported as the pioneer modern cardmist in Akwa Ibom State and probably in Southern Nigeria and Nigeria at large when considering his consistent pottery experiments in southern Nigeria since 1930 and his outstanding ceramics practice in Uyo since 1935.

This was probably the advent of contemporary or modern ceramics practice in the Niger Delta Region. Indigenous and contemporary pottery or ceramics practice had since been playing vital role in the sustenance of socio-economic wellbeing of the people of Niger Delta. It could still play a more significant role in the oil producing communities today especially now that oil extraction in the area is worsening poverty and as other bad behaviours due to the denial of oil producing communities ee employment and access to oil revenues.

When environment and economic development conditions deteriorate to unbearable level, the oil bearing communities naturally react. Instead of the multinational responding to the plight of the people positively, they rather responded by securing the assistance of federal government through the use of the Nigerian Police or military to terrorise and brutalize the protesters. Most of their complaints relate to unemployment, poverty, environment degradation, destruction of means of livelihood and health [10].

It is on this note that the study on reflection on pottery art in the oil rich Niger Delta Region is brought to bear which probably could provide the means to salvage plight of the people of Niger Delta communities today. The economy of many nations such as China, Japan and others have been boosted through manufacturing different wares made from clay., the abundant deposits of clay in various communities of Niger Delta area have the capacity to create numerous employment opportunities and significant economic fortunes to the people. Large scale of protection of clay works such as electrical insulators, sanitary wares, architectural ceramic wares, dinner wares and others in the Niger Delta are bound to alleviate people for excruciating poverty in the land.

This study hopefully is bound to highlight the importance of proper harnessing of production of wares from available abundant clay in the region to compliment oil extraction in the area for a more dynamic socio-economic growth of Niger Delta region.

\section{Methodology}

The researcher adopted a case study design in carrying out the activities of this research. The nine states of Niger Delta area were considered the population of the study. Among the states include, Abia, Akwa Ibom, Bayelsa, Cross River, Edo, Delta, Imo, Ondo and Rivers States. Virtually, every community in the region either produced or utilized indigenous pottery wares for domestic and socio-cultural purposes. Some of the areas witnessed the establishment of contemporary or modern pottery namely; Modern Ceramic Limited, Umuahia in Abia State which was established in 1962, Quality Ceramics Limited, Itu in Akwa Ibom State established in 1984, Calabar Pottery Centre established in 1969, Matthew Ceramics, Aboboro, in Rivers State and others.

It is apparent that this study cannot be carried out in all the states, and on this note the researcher considered choosing two most oil producing states in the region for an in-depth study of both indigenous and contemporary pottery or ceramics practice. The states include Akwa Ibom and Rivers States. The two States were chosen because they are the leading oil producing communities and also have high deposits of various types of clay. The study looks at the indigenous pottery practiced in Rivers State and specifically reflects on the Buan traditional pottery in Ogoni. While the aspect of contemporary pottery or modern ceramics, Ikot Ebom Itam Pottery or ceramics in Itu, Akwa Ibom State has been considered. In view of the two phases of pottery or ceramics practice in Niger Delta region one of the study places is in Akwa Ibom State and another in Rivers State respectively and these show the real state of possible wealth creation in the region through proper harnessing of clay deposited in the entire region.

The researcher made use of primary and secondary sources in carrying out the study. The primary sources involved the use of oral tradition through organizing series of interview with selected relevant persons. Direct observation of pottery activities and collection of information from other relevant sources. Secondary sources include the use using of published and unpublished works to acquire information. The adoption of inter-disciplinary 
approach was considered to check mate any short coming from one source of information where merit or demerit of another source could make up for a balance.

\section{DATA COLlEction AND ANALYSIS}

The researcher got photographs of pottery activities and wares from the pottery centres, Elderly and resource persons were interviewed. Visits to population site and observation were conducted, while other information were gathered from books and other written documents.

Photograph of selected pottery activities and products directly relevant to processes of material pottery were taken to boast the study. Among them include; matching of the clay, second matching of the clay and grog additions, the Buan "traditional clay water pot (unfired), the Buan "Traditional clay water pot (fired), site of Ikot Ebom Itam Pottery centre, jugs, mugs, and cups (glazed) produced at the centre and different pottery wares (products of Ikot Ebom Itam Pottery centre).

The suitability of pottery activity and the end-products which enhance the economy of the people show the ability to reflect the subject based on the purpose for evaluation and interpretation. The research was limited to only Akwa Ibom and Rivers States in view of their elaborate practice of pottery and availability of clay in abundance. Document analysis method considered quantitative research technique, where written materials with information intended to be investigates are analyzed.

\section{LITERATURE REVIEW}

\section{A. Pottery or Ceramics and Its Origin}

"Pottery is made by forming a clay body into objects of a required shape and heating them to high temperatures in a kiln which removes all water from the clay, which induces reactions that level to permanent change, include increasing their strength and hardening and setting their shape" [1].

The word "pottery" sometimes is interchanged with "ceramics". Ceramics or pottery are "things made or designed in clay with or without addition of other materials, then rendered permanent by application of suitable heat" [8]. The use of the word ceramics is more common with the Italians which originated from there, word "Keramos" which means ,baked ce clay. The English use the word pottery majorly. Pottery involves giving permanent form to designed pieces of clay after their creation. It was observed [6] that "the evidence of this form of art (Pottery) abounds in many ancient civilizations such as the Chinese, Egyptians, Greeks, and so on. In China, for example, the Yangshao culture, which existed between $7000-5000$ BC is historically known to have developed a technique of painted pottery vases".

The practice of pottery is an age-long technology which cut across virtually every human culture globally [18]. "pottery in its traditional setting is unique in the sense that it is manually made or formal else-where except by the potter himself or herself. The practice of the art of pottery can be perhaps attributed to two obvious reasons. First, the utilization purpose that, its products serve in various societies that produced it, and secondary, the availability of clay deposits in most parts of the world." He further stressed that "the sub-saharan African and African and particularly in Nigeria, the traditional pot making thrived for ages during the iron Age.

The Nok terra-cotta for instance, is considered by some authors, as an evidence of artists. Sophistication of Ancient African peoples and shared traits of both sculpture and ceramics alike" In the view of Tser, that ceramic or pottery all over the world is practiced where clay deposits are found is in line with this research which solicits from significant practice of ceramics in Niger Delta region due to the availability of clay in abundance. It is a natural endowment in the region and it requires its adequate utilization to alleviate poverty and generate good health for the wellbeing of the region and the people.

\section{B. Indigenous Pottery Practice of Buan in Rivers State}

Buan is a community in Ogoni, Rivers State and has an outstanding pottery tradition. It is one of the major occupations of the Buan people in Ogoni, Rivers State and has an outstanding pottery tradition. It is one of the major occupations of the Buan people in Ogoni Kingdom. Clay which is a valuable pottery raw material in references to as „laabae" in the local Ogoni parlance.

The evidence of pottery in Ogoni were found by a team of archaeologist at Nama cradle land of Ogoni, excavated by Prof. E J. Alagoa under the sponsorship of Ken SaroWiwa in 1985. Hence, pottery making is a common and fulltime occupation amongst the women of "Buan" in Ogoni. The aesthetic appeal of the "Buan" traditional pottery is very much hidden, hence contributing to low patronage and wide range of acceptance. Furthermore, the body of pottery after its production is mostly kept bare and undecorated. Although, some are coloured with a fluid squeezed from the back of mangrove tree, they usually wash off easily when in contact with water. This makes the pots less attractive. A critical observation reveals that the pots are constructed without a base, making it difficult for it to stand on its own when there is no external support. Hence the objective of this study is to improve the aesthetics of the, Buan "traditional pottery by introducing decorative symbolic motifs, providing a decorative base as support for pots produced as well as suggesting low cost glazing innovations to improve the quality pots produced for better patronage and wider acceptance [16].

The age-long pottery practice in Buan is mainly practiced by the women folk. Pottery plays a vital role in the culture of Ogoni people. The clay products are found in traditional ceremonies, domestics and social events, rituals and or other uses. The socio-economic life of the people got improved through the engagement of individuals and families in the indigenous pottery venture.

The Buan traditional ceramic centre [17] has some very unique approach in her style of pottery production. This is evident from the way they collect the clay, process them, build their pots, fire and glaze them. 


\section{1) Demonstrating the 'Buan' Pottery Production} Process

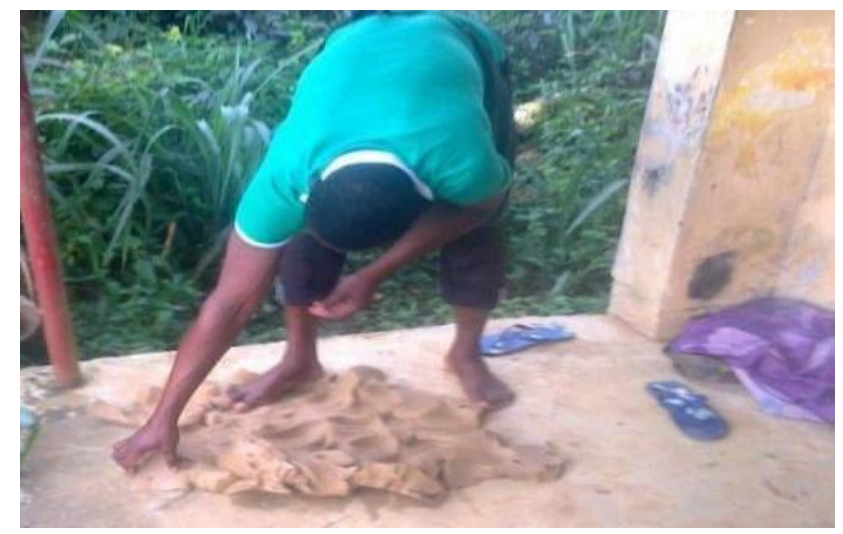

Fig. 1. Matching of the clay

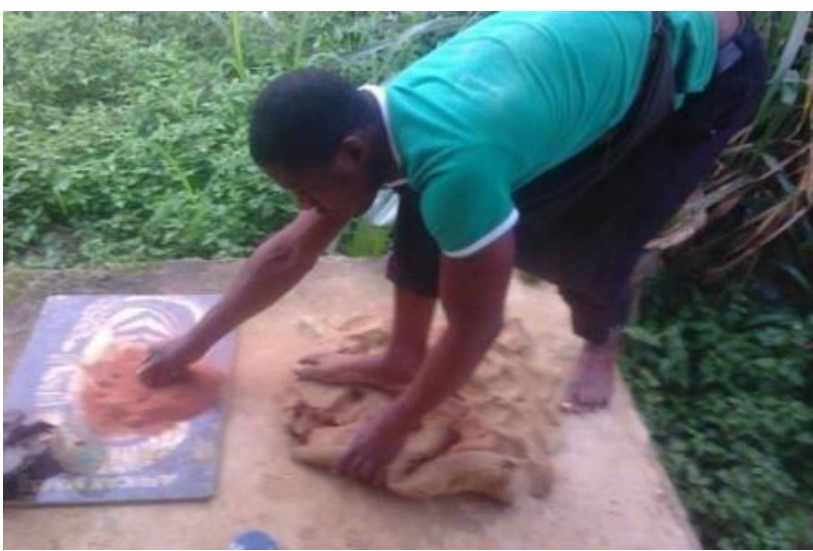

Fig. 2. Second matching of the clay and grog addition.

\section{2) Buan Traditional Pots}

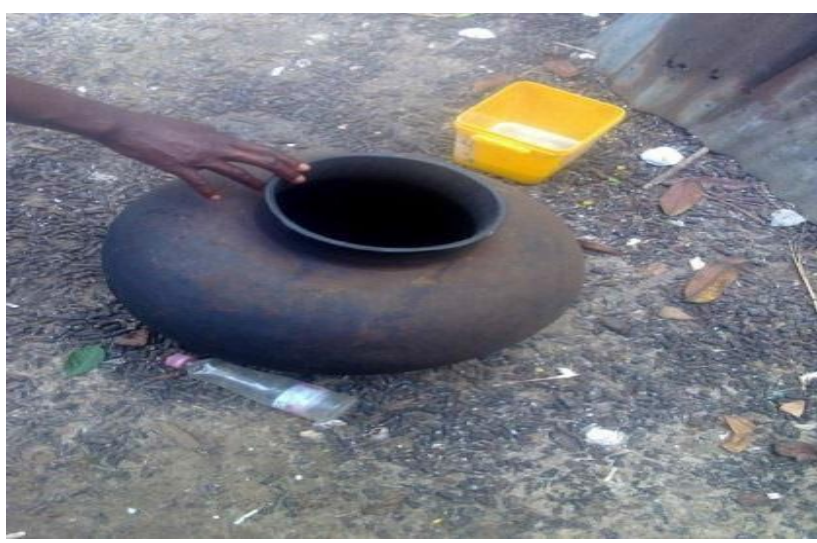

Fig. 3. The Buan ${ }^{e e}$ traditional clay Water Pot

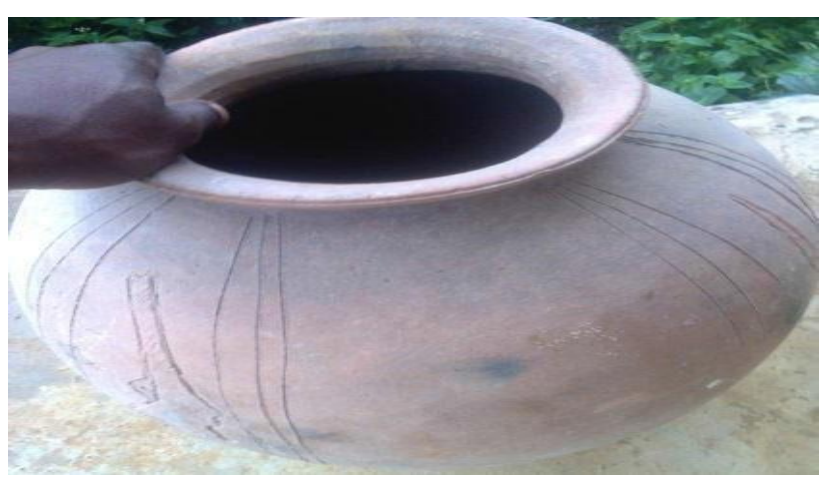

Fig. 4. The Buane traditional clay Water Pot (Fired)

\section{Contemporary Pottery or Ceramics in Ikot Ebom Itam, Akwa Ibom State}

The unique pottery encounter in Ikot Ebom Itam is worthy of note due to its series of transitions. The age-long indigenous pottery practice in Ikot Ebom Itam moved to a level of modern pottery in 1969 when a Catholic Reverend sister Louis Steen from Switzerland provided a word kiln, glazes and kicked wheels to kick-start the modern or contemporary pottery practice in the community. A large scale ceramic industrial company known as Quality Ceramics was established by the government in 1984 in the same community.

Pottery tradition has also metamorphosed into many phases ranging from orthodox practice era to the unorthodox phases of practice [12]. In the abundance of clay as the basic pottery raw material in the area has been a wonderful spur to their involvement in pottery craft.

According to an over 80 years old Elder Okon Anyang who was one of the most outstanding Elders in the said village, and whose grandmother and mother were experts in the craft, he said anybody who became anything in the area was as a result of this old time pottery craft. Since every family in those days was engaged in the pottery business, everybody was therefore benefiting from the art either directly or indirectly.

In the ancient days it was believed that the craft was specially meant for women and therefore men were not even allowed to venture into the quarry.

The economic well-being of the people and families experienced is boost through the income generate from pottery business.

According to Michael Edem Esau, one Emmanuel Simon Ekanem and himself were the first two people the management committee which was comprised of men and women, picked and sent for training. He was sent for training after his primary Education in 1970, and he spent one and half (1/2) years at Calabar for the training. Two of them had their training under Mr. Okon Edem of Ministry of Trade and Industry at No. 4 Atu Street, Calabar, and finished in 1972. They were further sent to Abuja for onemonth pottery craft training. When they came back, they trained six people where two were men and four were women. Some of them latter joined the Ministry of Industry. Reverend sister Louis who was pleased with the local women to see them using coil method to produce wares also assisted them to change from open firing to the use of kiln. While two potter's wheels were bought for throwing, they used plaster moulds forecast wares. The able leadership of women tinder their president Madam Mma Akpan Umana in 1969 involved women in bringing sand and gravels from the stream to assist build the pottery centre, Women were selected insets to quarry clay to one site for use. It was during this period, the Government sent two staff, Mr. Ubeh to start the centre while the following were under them Michael Edem Esau, Emmanuel Edem. Miss Akon Joshua Sam and Miss Elizabeth Edet Udofia. 


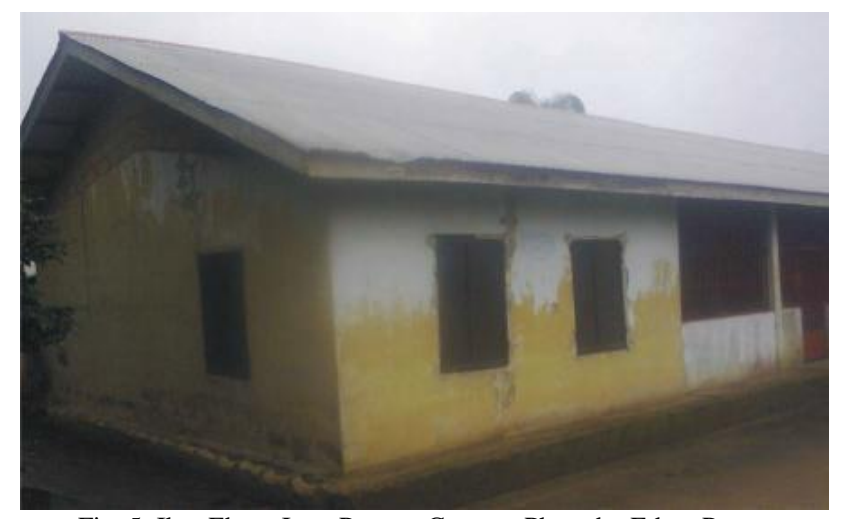

Fig. 5. Ikot Ebom Itam Pottery Centre - Photo by Edem Peters

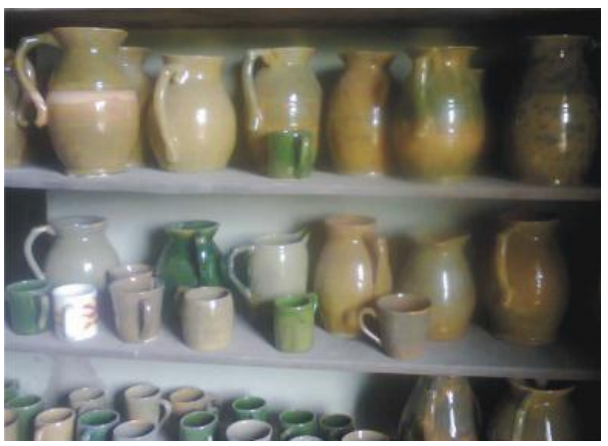

Fig. 6. Jugs, Mugs, and Cups (glazed) produced at the centre - Photo by Edem Peters

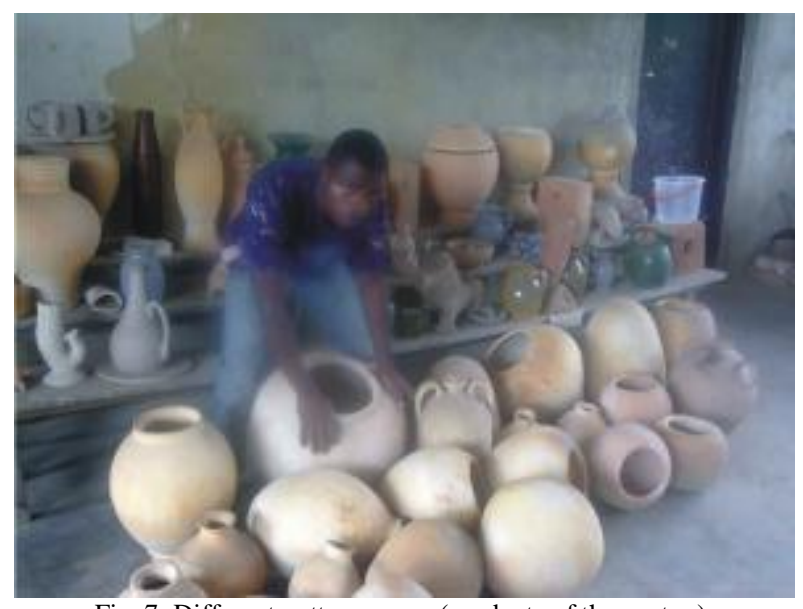

Fig. 7. Different pottery wares (products of the centre ). Photo by Edem Peters

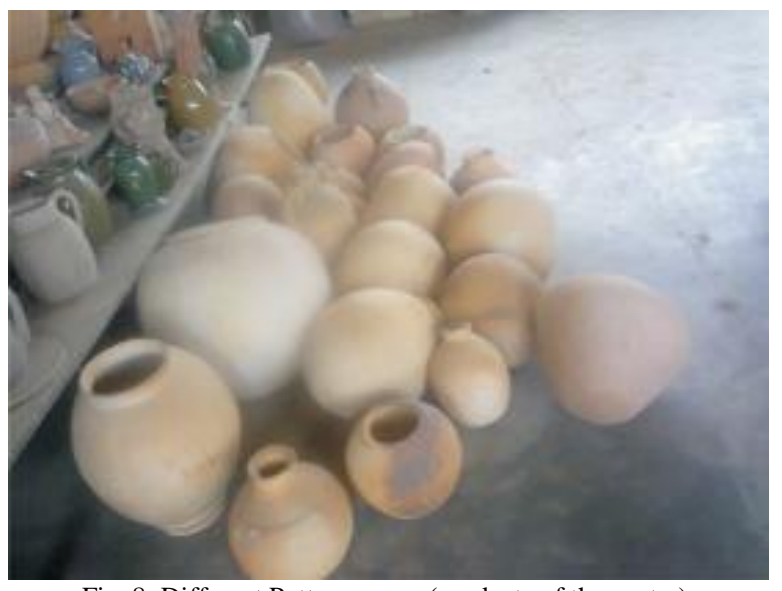

Fig. 8. Different Pottery wares (products of the centre). Photo by Edem Peters

\section{The Growth of Modern Practice in Akwa Ibom State}

There are clear features which distinguish modern ceramics or contemporary ceramics from the indigenous or traditional pottery. Indigenous pottery products are produced from secondary days and fired at low temperatures majorly in an open firing device. Modern pottery or ceramics makes use of machinery to ease the creation of various designs, application of glaze on wares and firing using kiln to high temperatures.

The return of an indigenous pioneer potter Chief Adam Joshua Udo Ema (Etinan) from Great Britain in 1949 who later worked as an assistant pottery officer at Okigwe pottery centre before coming to work in Akwa Ibom in 1955 heralded serious modern pottery in Akwa Ibom State. Chief Ema established three pottery centres in Akwa Ibom State among them include pottery centre at Mbiafun Ikono in Eastern Ibibio Ikono, pottery centre at Ikot Ntot in Abak Local Government centre and Ikot Abasi I pottery centre in Etinan Local government centre. Wood kilns were built and wares were glazed with the advent of establishment of the pottery centres. Training of man power was eminent and some of those who were trained include chief Okon Edem of Ikot Abasi No.I (Etinan Local Government Akwa Ibom Aned) at Ekulu (Enugu) and Japan. Mr. J.U. Umoh and Mr. Peter Essien both from Ikono Local Government Area of Akwa Ibom State in Nigeria were also trained in Okigwe and later Japan as well as Italy.

Many Akwa Ibom indigenes were involved in the establishment of pottery centre after their training within and outside Nigeria. The training of indigenes of Akwa Ibom in different countries such as Japan, Germany, Italy and Britain brought great influence to the era of modern pottery or ceramics in Akwa Ibom State and outside the State. Some of them were at Okigwe Pottery training centre, Modern Ceramics, Umuahia in Abia State and Calabar Pottery centre in Cross River State.

The training programme took place at Okigwe pottery centre and Ekulu (Enugu) pottery training centre at lva valley in Enugu. In 1962 when modern ceramics industry, Umuahia was established and some of them were given opportunities to work there as well as further trained in Germany for the upkeep of the ceramics industry. Chief Okon Edem who become the production manager at the modern ceramics later worked with the ministry of industry Calabar after the Nigerian civil war. He established Calabar pottery centre at No.4 Atu Street Calabar in 1969. While Akwa Ibom State then called "Mainland" was in the southern part of the Southeastern State of Nigeria. Ikot Ebom-Itam pottery (Akwa Ibom State) was established in 1971 by the community with the help of a Catholic Reverend sister Louis Steen (Switzerland) who worked then in Anua, Uyo [14].

Akwa Ibom State is a unique community noted for early indigenous and contemporary ceramic practice. The area is blessed naturally with abundant clay raw material as well as crude oil and other minerals. The state could be given the opportunity to pilot the training and equipping the youths of Niger Delta region with contemporary pottery skill to boost creating employment opportunities and self-reliance. The Pottery infleucne of Kenneth Murray, Chief Adam Joshua Udo Ema and Chief Okon Edem among others over eighty 
years ago in Akwa Ibom State has impacted greatly in pottery experience and skills of the people. Murray advocated the modern pottery approach in the area [11].

Murray returned from Ibadan to government college, Umuahia later in 1934, and some of his special students joined him there. He moved southwards to Uyo in 1935 to teach at the elementary Training College (ETC). It was at Uyo in December 1935 that he admitted the youngest of his five special students. His name was A. P. Umana, aged fifteen. During this period in Uyo (1935-7) Murray carried out extensive studies of extant vernacular arts and crafts in the area. He built another kiln for the boys and taught them how to fire their clay models.

The practice of ceramics in the Niger Delta region requires the goodwill of the people and government for proper implementation and encouragement. The fabrication of ceramics kiln and equipment locally alongside the production of ceramic wares is an age-long practice in the area.

Murray is regarded as the pioneer modern ceramist in Akwa Ibom and probably in southern Nigeria and Nigeria at large when looking at his consistent pottery experiments in Southern Nigeria since 1930 and his outstanding ceramics practice in Uyo since 1935. The researcher's personal interview with chief Adam Joshua Udo Ema in 1992 attest to the fact that Udo Ema had a very close relationship with Kenneth Murray although he was not among the five (special) students of Murray-among there are Ibrahim, Ibeto, Enwonwu, Nnachy, and Umana. Chief Udo Ema probably was inspired by ceramics experiments of Kenneth Murray which he later in 1949 studied pottery in Britain [16].

\section{OBSERVATION}

Niger Delta Region is naturally endowed with resources such as clay, crude oil, fisheries, fertile land and others which could bring out-standing development to the region if well harnessed. This requires an effort in the area of human resource development to match with the much available natural resources found in region. Ibid [5] opined that, "Development must involve the mobilization of people and their resources for the ultimate goals of exploring and exploiting the natural environment to serve their material needs and social wellbeing".

The over dependent on oil and gas and mad rush to drill enormous quantify on daily basis without any concrete thought of reservation is indeed very worrisome and suicidal. It is high time alternative natural endowment „clay ${ }^{\text {ee }}$ which is found in abundance be explored and utilized for maximum benefit of the region and the nation while the level of oil exploitation should be minimized as done in other civilized nations of the world such as United State of American (USA).

The material needs and socio-economic well-being of the people of Niger Delta region could comfortably be taken good care of through large scale utilization of the abundant clay in the region.

"The shapes and designs of pottery wares are unique and are identified with different places or cultures [15]. Pottery or ceramics products are designed to suit the function and the background or culture the products are made, and so should Niger Delta cultural background be identified with the envisaged ceramic products. "Improved productivity has to do with the quality and design of a product which makes it outstanding among other similar products in the market [9]. As a result of this the utilitarian value of the ceramic products as well as its market demand are increased".

The universal pricing of oil and gas is not applicable to ceramics or pottery products since unique designs and functions of ceramics product command suitable varying pricing of products. This is of great consideration when taking advantage of the situation to boost Niger Delta Region economy through exploring and exploiting clay to meet our socio- economic yearnings.

\section{CONCLUSION}

The exploitation of clay in the Niger Delta Region for outstanding development will generate no economic and socio-political problems which could impact negatively on the communities, as the case with oil exploration. "The advent of shell's oil exploration in Ogoni Community interfered with and disrupted their traditional occupation which is centered on farming and fishing activities [4]. Therefore the main economic and traditional means of livelihood of the people were truncated due to shell's oil exploitation activities. This deprivation of economic means of survival made the people jobless and vulnerable to shell's manipulation and control. Ogoni people are faced with myriad of problems that were considered uncommon before the commencement of oil exploration and exploitation by shell'. The exploitation of clay for ceramic production in never intimidating to the people nor the environment, but rather boost the advancement of the people and environment.

"The historical origins of pottery making in the old world and the new would cover different areas such as raw materials of ceramics or pottery, manufacture, tribe, various transaction with pottery or ceramics product today. It also envisages the technical characteristics of pottery and modern changes in manufacture and use of the product. The w wares are described by the materials and techniques they display, and pottery or ceramics is notably recognized as the product of day and other earthy material. The productions of electrical insulators of different kinds for the modern use holds the idea of time which reflects the new world and not historical or prehistoric time".

The findings from the study about the ages-long pottery practice which show progressive transformation from traditional to modern practice has the capacity to grow to large scale ceramic industries. The production of pottery or ceramics accommodate the illiterate and literate members of the society, females and males, individuals and organizations. The productions of ceramics are always appealing and play the role of utilitarian and aesthetic functions, as well as generating employment opportunities through establishment of cottage and large-scale industries.

A summary of the reflections on pottery practice in Niger Delta Region with a view on the indigenous and modern pottery or ceramics production will be that the exploration and exploitation of abundant clay in Niger Delta area will advance the development of the area instead of intimidating the people and the environment. The income yieldings from 
oil, gas and other natural resources are appraised, but the one that is commendable is the view of clay utilization for various large-scale pottery or ceramic production is crucial in the sincere development effort of Niger Delta Region.

\section{ACKNOWLEDGMENT}

I wish to thank the Almighty God for His blessings, good health, care and right frame of mind to concentrate in my scholarly work.

I would like to thank Professor A. A. Derefaka of the Institute of Niger Delta Studies who supported me with some materials and other information during the cause of this study. I wish to appreciate Mrs. Charlotte Tan-George, Dr. N. Ubogu, all those who gave me useful information, and those who typed the work or contribute in whatever way to the successful competition of this study. Finally, immense appreciation goes to my wife, Eno E. Peters for her constant support and encouragement.

\section{REFERENCES}

[1] Arnold, E. D.: Ceramic theory and Cultural process. (Cambridge University Press). Cambridge, 1989.

[2] CBN: Central Bank of Nigeria statistical Bulletin, 2011.

[3] Duru, E. J.: Oil Multi-national and the Niger Delta Crises; Issues and Perspective, Owerri: African Scholars publishing, 1999.

[4] Gbenenye, E. M.: Ogoni Struggle for Resource Control. Lesson for managing the Niger Delta Conflicts; Journal of Nigeria Delta studies, University of Port Harcourt. Vol 3, 2014, Mo. 2, 2014.

[5] Ibia, T. O., The impact of the University of Nigeria on the Development of Akwa Ibom State. A paper presentation on the occasion of a seminar organized by the Akumni of University of Nigeria, Nsukka (Akwa Ibom Chapter), Uyo, University of Uyo, 2010.

[6] Liu, L. The Chinese Neolithic: Trajectories to early states, New Studies in archaeology, combridge, U.K Cambridge University Press, (2004).

[7] Nicklin, K. "Pottery Production and Distribution in South-east Nigeria". A Ceramic View Point, Ed. Howard H. and Ecine L. Morris. Bar International Series, (1981).

[8] Peters, E. E.: The use of Ceramics Relief Panels in Preservation of Akwa Ibom State Traditional Musical Instruments. A research project submitted in partial fulfilment of the requirements for the award of the Bachelor of Arts Degree in Fine Arts (Ceramics) Department of Fine and Industrial Arts, University of Uyo. 1990.

[9] Mathew, K. T.: Promoting partnership among Private ceramics firms/practitioners and tertiary institutions in Nigeria for empowered Ceramics productivity; Ashakwu Journal of Ceramics, Ceramics Researchers Association of Nigeria (CeRAN), vol. 12, June, 2015 p. 142.

[10] Nwiyondee, A. N., \& Ihenetu, H. I.: Microfinance: A veritable tool for addressing the challenges of poverty and criminality in Niger Delta Region. Journal of Niger Delta Studies, University of Port Harcourt: Volume 3, 2014, No. 2, 2014

[11] Onuzulike, O.: The Emergence of Modern Ceramics in Nigeria: The Kenneth Murray Decade, 1929-39. The Journal of Modern Craft, Volume 6 Issue 3 November 2013, pp.293-314. Bloomsbury Publishing Plc.
[12] Peters, E. E.: History of Kiln Construction for ceramics practice in Nigeria, Design History in Nigeria, Abuja, National Gallery of Art and Association of African Industrial Designers (pp. 71-78), 2002.

[13] Peters, E. E.: Ikot Ebom Itam Pottery in Ibibio art and Technology. The Past and Present. International Journal of Arts and Cultures in Society Vol. 4 Numbers 3, 2012. Accra, PanAfrican Bodies with JIMST. P. 9 - 19

[14] Peters, E. E.: The Rise and full of pottery practices in Akwa Ibom State in Nigeria. Journal of Engineering \& Environmental studies, Olabisi Onabanjo University, Ogun State Nigeria: Volume 4 No. 1 2015.

[15] Peters, Edem E.: Ceramic Technology and Electrical Power generation; Journal of Engineering and Environmental studies, Olabisi Onabanjo University, Ogun State, Vol. 5 No.2, 2014.

[16] Peters, Edem E.: Ceramic! The Art and the Business Potential. The unique entrepreneur. The Maiden Edition. The Business Magazine for Investors, Innovators and Inventors. Port Harcourt; University of Port Harcourt, Vol. 01, No. 1, June 2015.

[17] Tam- George C. and Peters, E. E.: esthetic improvement of Buan Traditional Pottery for integration into modern ceramic. Design Review Journal of Industrial Design: Zaria Vol 42015

[18] Tser, H. N.: Trends in contemporary African Patterns: A case study of Levi O"Ben Yakubu: Ashiuwu: Journal of Ceramic a Ceramics Research Association of Nigeria (CRAN) Zaria, Vol. 14 June, 2008 , 2017.

[19] Umoh, J. J.: The Impact of Religion on Pottery Practice in Ibibio land, South-South, Nigeria. Journal of Ceramics and Environmental Design, Port Harcourt: Vol. 4, No. 22017.

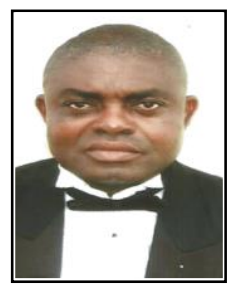

Edem E. Peters hails from Nkana-Iman, Etinan Local Government Authority Area, Akwa Ibom State, Nigeria. He holds B.A Hons. (Fine/industrial arts Ceramics), Uyo, Nigeria; M.F.A (Ceramics), University of Nigeria, Nsukka, Nigeria; M.Ed. (Educational Technology), University of Port Harcourt, Port Harcourt, Nigeria, and Ph.D. (Art Education) University of Nigeria, Nsukka, Nigeria $\mathrm{He}$ has also been awarded Certificate after his successful completion of a short course on Kiln Building and Firing Techniques in the Summer Ceramics Programme of 2012 Sessions, Morternhampstead, United Kingdom.

$\mathrm{He}$ is a senior lecturer in the Department of Fine Arts and Design, University of Port Harcourt, Port Harcourt. He is a member of Ceramics Research Association of Nigeria (CerAN), Craft Potters' Association of Nigeria (CPAN), Society of Nigeria Artist (SNA), University of Nigeria Nsukka Alumni Association, and others etc. He has participated in several joint and solo exhibitions as well as trade fares. He has received many honours/awards and has visited great pottery Centres/Potters like Svend Bayer (Beaworthy; Devon), Douglas Fitch (Crediton, Devon), Nic Collins (Morternhampstead), Leach Pottery (St. Ives, Cornwall) and numerous others in the United Kingdom and Wales.

Dr. Peters is well published in Arts/Ceramics journals and other publications, and has also carried out many researches. Among his publications include: A book titled - Entrepreneurship Development: Management and Practice - Issues in Visual Art, Industrial Design and Technology. Port Harcourt; University of Port Harcourt Press 2016;

A chapter in a book titled - History of Kiln Construction for Ceramics Practice in Nigeria. Design History in Nigeria Essays in Honour of Demas Nwoko. Department of Creative Art, University of Port Harcourt, Port Harcourt. First Published in Nigeria by: National Gallery of Art, Abuja and Association of African Industrial Designers. ISBN 978-33527-7-2. Pp. 7178. 2002; and a journal paper titled - The Impact of Ceramics Technology in the Development of Akwa Ibom State in Nigeria. International Journal of Advanced Research. (August 31) Issue, Volume 4, ISSN No. 2320-5407. United Kingdom 2016.

$\mathrm{He}$ is a Ceramics consultant and has traveled to many countries and his works are in many homes and places within and outside Nigeria. 